\title{
Hemşirelerin Bası Yarasını Önleme ve Yönetme Bilgisi
}

\author{
Sevim Çelik ${ }^{1}$, Elif Dirimeşe ${ }^{1}$, Nurten Taşdemir ${ }^{1}$, Şefika Aşık ${ }^{1}$, Sevim Demircan", \\ Sena Eyican', Büşra Güven ${ }^{1}$ \\ ${ }^{1}$ Bülent Ecevit Üniversitesi, Zonguldak Sağlık Yüksekokulu, Hemşirelik Bölümü, Zonguldak
}

\begin{abstract}
ÖZET
Hemşirelerin bası yarasını önleme ve yönetme bilgisi

Amaç: Bu çalışmanın amacı, hemşirelerin hospitalize edilen hastalarda bası yarasını önlemeye ve yönetmeye yönelik bilgi düzeylerini ve etkileyen faktörleri belirlemektir.

Gereç ve Yöntem: Bu tanımlayıcı kesitsel araştırma, Zonguldak'taki üniversite ve devlet hastanelerinde çalışan 523 hemşire ile gerçekleştirildi. Veriler, Avrupa Basınç Ülseri Danışma Paneli ve Ulusal Basınç Ülseri Danışma Paneli rehberlerine dayanılarak geliştirilen anket ve kişisel bilgi formu kullanılarak Mart-Mayıs 2014 tarihleri arasında toplandı. Veriler; bağımsız değişkenlerde t testi, tek yönlü ANOVA, Kruskal Wallis testi ve Pearson Korelasyon testleri kullanılarak değerlendirildi.

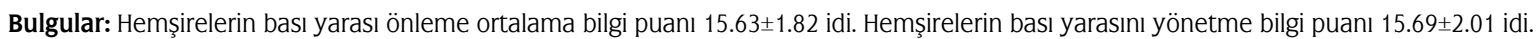
Devlet hastanesinde ve dahili birimlerde çalışan ve hizmet içi eğitim alan hemşirelerin bası yarasını önlemeye yönelik bilgi puanı anlamlı şekilde yüksekti $(\mathrm{p}<0.05)$. Devlet hastanesinde ve acil birimlerde çalışan ve hizmet içi eğitim alan hemşirelerin bası yarasını yönetmeye yönelik bilgi puanı anlamlı şekilde yüksekti ( $p<0.05)$. Hemşirelerin yaşı, çalışma yılı, çalışı̆̆ı birim, cinsiyeti ve bilgi kaynakları basınç yarasını yönetmeye yönelik bilgi puanı ile anlamlı ilişki gösterdi $(p<0.05)$.

Sonuç: Hemşirelerin bası yarasını önlemeye ve yönetmeye yönelik bilgisi orta düzeyde idi. Bilgi puanları hemşirelerin özelliklerinden anlamlı şekilde etkilenmişti. Bu bulgular bu alandaki çalışmalara ve eğitim stratejilerine katkı sağlayacaktır.
\end{abstract}

Anahtar kelimeler: Bası yarası, önleme, yönetme, bilgi, hemşire

\section{ABSTRACT \\ Pressure sore prevention and treatment knowledge of nurses}

objective: The aims of the study were to determine nurses' level of knowledge of pressure sore prevention and treatment on the hospitalized patients and affecting factors.

Material and Methods: This descriptive, cross-sectional study was conducted on 523 nurses working in a university and state hospitals in Zonguldak. Data were collected between March and May 2014, using a personal information form, questionnaire which was developed based on European Pressure Ulcers Advisory Panel and National Pressure Ulcers Advisory Panel guidelines. Data were analyzed by Independent samples $t$ test, One way ANOVA, Kruskal-Wallis, and Pearson correlation tests.

Results: The mean knowledge score about prevention of pressure sore of the nurses was $15.63 \pm 1.82$. The mean knowledge score about management of pressure sore of nurses was $15.69 \pm 2.01$. The knowledge scores about prevention for pressure sore were significantly increased among nurses worked in state hospital and medical department, attended in-service training ( $<<0.05)$. The knowledge scores about management for pressure sore were significantly increased among nurses worked in state hospital and emergency department, attended in-service training $(\mathrm{p}<0.05)$. The mean age, working years, gender, department, knowledge sources of nurses showed significantly an association with knowledge score of management for pressure sore $(p<0.05)$.

Conclusions: Knowledge about pressure sore prevention and management of nurses was moderate level. The knowledge scores were significantly affected by the nurses' characteristics. These results will contribute to studies and education strategies in this area.

Key words: Pressure sore, prevention, management, knowledge, nurse

Bakırköy Tıp Dergisi 2017;13:133-139

Yazısma adresi / Address reprint requests to: Sevim Celik, Bülent Ecevit Üniversitesi, Zonguldak Sağlık Yüksekokulu, Hemşirelik Bölümü, ibn-i Sina Kampüsü, Abaz mevkii, Zonguldak Elektronik posta adresi / E-mail address: sevimakcel@yahoo.com Geliş tarihi / Date of receipt: 01 Ağustos 2016 / August 01, 2016

Kabul tarihi / Date of acceptance: 05 Eylül 2016 / September 5, 2016 


\section{Giriş}

B ası yarası Avrupa Basınç Ülseri Danışma Paneli (EPUAP) ve Ulusal Basınç Ülseri Danışma Paneli (NPUAP) tarafından, "Tek başına, basınç ya da yırtılma ile basıncın bir arada sebep olduğu, genellikle kemik çıkıntılar üzerinde ortaya çıkan lokalize deri ve / veya deri altı doku hasarı" olarak tanımlanmaktadır (1). Bası yarası, tüm dünyada hastanın yaşam kalitesini etkileyen ve sağılı bakım maliyetini arttıran önemli bir problemi olarak belirtilmektedir (2). Vücudun özellikle kemik çıkıntılarının bulunduğu bölgelerde uzun süreli ya da tekrarlayan basılara bağlı olarak deri ve derialtı dokularda kapilerlerin tamamen kapanması ve o bölgede dolaşımın durması sonucu ortaya çıkar $(3,4)$. Hastanın fiziksel sağlığını etkileyerek yaşamını tehdit etmenin yanı sıra, bağımsızIığını kaybetme, sosyal izolasyon gibi psikolojik problemlere yol açmaktadır. çoğu zaman da hastanede kalış süresini uzatmakta ve hemşirenin bakım için daha çok zaman ayırmasına neden olmaktadır (5). Bası yarası büyük oranda önlenebilir olmasına karşın sağlık bakım sisteminde önemli bir sorun olmaya devam etmektedir. Bası yaraları bir kez oluştuğunda tedavisi son derece güçtür $(5,6)$. Cerrahi yöntemlerle kapatılan yaralarda \%95'e varan yineleme oranı bildirilmiştir. Bu nedenle en etkin tedavi, risk altındaki hastaların tanınması ve bası yarası açılmasının önlenmesidir (7). Bası yarası, sağlık bakım sisteminde kalite göstergelerinden biri olarak ele alınmakta olup, önlenmesi ve tedavisi multi disipliner ekip yaklaşımını gerektirmektedir. Bu süreçte en önemli rol, multidisipliner ekibin değişmez üyelerinden biri olan ve hastaya 24 saat hizmet veren hemşireye düşmektedir $(2,8)$. Bireyi ve aileyi fizyolojik, psikolojik ve ekonomik yönden ciddi şekilde etkileyen bası yarasının önlenmesi hemşireler için bakımın merkezinde yer alan öncelikli ve profesyonel bir sorumluluktur (9). Ulusal Basınç Ülseri Tavsiye Paneli'nin (NPUAP-2001) 1990-2000 yılları arasında yapııımış olan 300 çalışmanın sonuçlarına dayanarak hazırladığı rapora göre, Amerika Birleşik Devletleri'nde bası yarasının insidansı akut bakım alanlarında \%0.4-38, uzun süreli bakım alanlarında \%2.2-23.9 ve evde bakımda \%0- 17'dir (2). Avrupa'da yapılan çalışmalarda bası yarası yaygınlık tahminleri \%8.3'den \%25.1'e çıkmıştır (7). Ülkemizde yapılan çalışmalarda cerrahi hastalarda bası yara insidansını \%54.8, prevelansını \%7.8 olarak belirlemişlerdir. Bu çalışmalar önleyici uygulamalarla ilgili inmalin ve hemşirelik bakım kalite- sinde yetersizliğin bir göstergesi olarak kabul edilmektedir $(3,10)$. Bası yarası oluşumunda rolü olan risk etmenlerini belirleyip bunlara karşı gerekli önlemlerin alınmasının yanında yaraların tedavisi de hemşirenin sorumluluğundadır (11). Hastada bası yarası mevcut olsa bile iy bir hemşirelik bakımı ile daha kısa sürede tedavi edilebilir. Hemşirenin etkili bir bakım sağlaması için de bilgi düzeyi önemlidir. Bilgi düzeyi ne kadar yüksek olursa verilen bakımın kalitesi o derece artar. Hemşirelerin bakımın kalitesini arttırmak için yaptığı her girişim bası yarasını önleme ve tedavi etmede önemli bir faktördür $(2,9,12)$.

Hemşirelerin bası yarasını önleme ve yönetme bilgisine yönelik yapılan önceki çalışmalarda düşük, yeterli ve yüksek düzeyde olarak çeşitli sonuçlar elde edilmiştir. Türkiye'de bu konuya yönelik çok az sayıda çalışmanın olduğu görülmüş olup güncel çalışma, Zonguldak Ili'nde çalışan hemşirelerin bası yarasını önleme ve tedavi etmeye yönelik bilgi düzeyini değerlendirmek amacıyla gerçekleştirildi.

\section{GEREÇ VE YÖNTEM}

\section{Araştırmanın Şekli}

Bu araştırma kesitsel tipte tanımlayıcı çalışma olarak gerçekleştirildi.

\section{Araştırmanın Evren ve örneklemi}

Zonguldak ili'nde en yüksek yatak kapasitesine ve hemşire sayısına sahip Bülent Ecevit Üniversitesi Uygulama ve Araştırma Hastanesi'nde çalışan 407 hemşire ile Zonguldak Atatürk Devlet Hastanesi'nde çalışan 324 hemşire olmak üzere toplam 731 hemşire araştırmanın evrenini oluşturdu. Araştırmada örneklem seçimine gidilmemiş olup tüm evrene ulaşılması hedeflendi. Hastanelerde aktif olarak çalışan, araştırmaya katılmak isteyen, 18 yaş ve üzeri olan, Türkçe konuşup anlayabilen Bülent Ecevit Üniversitesi Uygulama ve Araştırma Hastanesi'nden 290 hemşire, Zonguldak Atatürk Devlet Hastanesi'nden 233 hemşire olmak üzere toplam 523 hemşire örnekleme dahil edildi. Araştırmaya katılmayı kabul etmeyen, izinli ya da raporlu Bülent Ecevit Üniversitesi Uygulama ve Araştırma Hastanesi'nden 113 hemşire, Zonguldak Atatürk Devlet Hastanesi'nden 98 hemşire örneklem dışı bırakıldı. 


\section{Veri Toplama Araçları}

Veriler, hemşirelerin demografik özelliklerini ve hemşirelerin bası yarasını önleme ve tedaviye yönelik bilgilerini değerlendiren, EPUAP (Europa Pressure Ulcers Advisory Panel) ve NPUAP (National Pressure Ulcers Advisory Panel) $(6,7,11)$ kaynaklarından yararlanılarak oluşturulan veri toplama formu kullanılarak toplandı. Bu form iki bölümden oluşmuştur. Birinci bölümde hemşirelerin cinsiyeti, yaşı, eğitim durumu, çalıştığı kurumu, çalıştığı servisi, çalışma deneyimi, basınç yarası hakkındaki bilgi kaynaklarını, hizmet içi eğitime ne zaman katıldıklarını ve bası yarası olan hastaya bakım verme durumunu değerlendiren dokuz kapalı uçlu soru yer almaktadır. íkinci bölümde bası yarasını önlemeye yönelik 20 açık uçlu, tedavi etmeye yönelik 20 açı uçlu olmak üzere toplam 40 soru bulunmaktadır. İkinci bölümdeki önlemeye yönelik bilgi değerlendirme anketinden alınacak en düşük puan 0 , en yüksek ise 20 puan; tedavi etmeye yönelik bilgi anketinden de en düşük puan 0 , en yüksek ise 20 puandır.

\section{Veri Toplama Süreci}

Veriler belirtilen anketler kullanılarak Mart-Mayıs 2014 tarihleri arasında toplandı. Görüşmeler mesai saatleri içerisinde her hastaneye gidilerek hemşirenin kendisi tarafından belirlenen uygun bir zamanda yapıldı. Bir anketin uygulanması yaklaşık 10 dakika sürdü.

\section{Verilerin Değerlendirilmesi}

Veriler SPSS 16.0 paket programına girildi. Hemşirelerin demografik özellikleri ve bası yarasını önleme ve tedaviye yönelik bilgileri sayı, yüzde, aritmetik ortalama ve standart sapma hesaplamaları ile değerlendirildi. Hemşirelerin bası yarasını önleme ve tedavi hakkında bilgi düzeyi ile demografik özellikleri arasındaki anlamlılığı değerlendirmek için Pearson korelasyon analizi, bağımsız değişkenlerde $t$ testi, tek yönlü- ANOVA ve Kruskall Wallis testleri kullanıldı. Anlamlılı $p<0.05$ düzeyinde kabul edildi.

\section{Etik Yaklaşım}

Verilerin toplanması için Bülent Ecevit Üniversitesi Klinik Araştırmalar Etik Kurulu'ndan (2014/03-13), ilgili has- tanelerin Başhekimliği ve Hemşirelik Hizmetleri Müdürlüğü'nden yazılı onay alındı. Araştırmanın amacı hakkında ve verilerin sadece bilimsel amaçılı kullanılacağı konusunda bilgi verilen hemşirelerden de sözlü olarak onay alındı.

\section{BULGULAR}

Araştırmaya katılan hemşirelerin çoğunluğunun (\%87.4) kadın, \%50.5'inin 29-38 yaş grubunda, \%64.2'sinin lisans mezunu olduğu, \%55.4'ünün üniversite hastanesinde ve \%47'sinin dahili birimlerde çalıştığı, \%39.2'sinin 0-5 yıldır hemşire olarak görev yaptığı belirlendi. Hemşirelerin \%74.4' nün bası yarasını önleme ve tedavi etmeye yönelik bilgi kaynağının hizmetiçi eğitimler olduğu, \%29.4'ünün bu eğitimlere katılmasının üzerinde 2 yıldan daha fazla zamanın geçtiği, \%78.2'sinin bası yarası olan hastaya bakım verdiği saptandı (Tablo 1).

Hemşirelerin bası yarasını önlemeye yönelik bilgi anketinden ortalama $15.63 \pm 1.82$ ve tedavi etmeye/ yönetmeye yönelik bilgi anketinden ortalama 15.69 \pm 2.01 puan aldıkları belirlendi. Tablo 2 incelendiğinde; devlet hastanesinde ve dahili birimlerde çalışan, hizmet içi eğitim alan hemşirelerin bası yarasını önlemeye yönelik bilgi puan ortalamaları istatistiksel olarak anlamlı şekilde daha yüksek olduğu bulundu $(p<0.05)$. Aynı tabloda, hemşirelerin yaş ve çalıșma yılı ortalamaları ile bası yarasını tedavi etmeye yönelik bilgi puan ortalaması arasında pozitif yönde zayıf bir ilişki saptandı. Buna göre yaş ve çalışma yılı arttıkça bası yarasın tedavi etme bilgisi de artmaktadır. Kadın olanların, acil birimde çalışanların, hizmet içi eğitim alanların bası yarasını tedavi etmeye yönelik bilgi puan ortalamalarının istatistiksel açıdan da anlamlı şekilde yüksek olduğu belirlendi $(p<0.05)$. Diğer demografik değişkenler ile hemşirelerin bası yarasını önlemeye ve tedavi etmeye yönelik bilgi puan ortalamaları arasından istatistiksel anlamlı farklılık bulunmadı ( $p>0.05$ ). Aynı tabloda; devlet hastanesinde ve dahili birimlerde çalışan, hizmet içi eğitim alan hemşirelerin bası yarasını önlemeye yönelik bilgi puan ortalamaları istatistiksel olarak anlamlı şekilde daha yüksek olduğu belirlendi $(p<0.05)$. Aynı tabloda, hemşirelerin yaş ve çalışma yılı ortalamaları ile bas yarasını tedavi etmeye yönelik bilgi puan ortalaması arasında pozitif yönde zayıf bir ilişki saptandı Buna göre yaş ve çalışma yılı arttıkça bası yarasını tedavi etme bilgisi de artmaktadır. Kadın olanların, acil birimde çalışan- 
Tablo 1: Hemşirelerin demografik özellikleri ( $\mathrm{N}=523)$

\begin{tabular}{|c|c|c|}
\hline Demografik özellikler & $\mathrm{n}$ & $\%$ \\
\hline \multicolumn{3}{|l|}{ Cinsiyet } \\
\hline Kadın & 457 & 87.4 \\
\hline Erkek & 66 & 12.6 \\
\hline \multicolumn{3}{|l|}{ Yaş } \\
\hline 19-28 & 202 & 38.6 \\
\hline $29-38$ & 264 & 50.5 \\
\hline $39-48$ & 47 & 9.0 \\
\hline $49-58$ & 10 & 1.9 \\
\hline \multicolumn{3}{|l|}{ Eğitim durumu } \\
\hline Sağlık Meslek Lisesi & 81 & 15.5 \\
\hline Önlisans & 82 & 15.7 \\
\hline Lisans & 336 & 64.2 \\
\hline Yüksek Lisans & 24 & 4.6 \\
\hline \multicolumn{3}{|l|}{ Çalıştığı kurum } \\
\hline Devlet hastanesi & 233 & 44.6 \\
\hline Üniversite hastanesi & 290 & 55.4 \\
\hline \multicolumn{3}{|l|}{ Çalıştığı servis } \\
\hline Dahili birimler & 246 & 47.0 \\
\hline Cerrahi birimler & 132 & 25.2 \\
\hline Yoğun bakım & 102 & 19.5 \\
\hline Acil & 43 & 8.2 \\
\hline \multicolumn{3}{|l|}{ Çalışma deneyimi } \\
\hline $0-5$ yll & 205 & 39.2 \\
\hline $6-10$ yll & 141 & 27.0 \\
\hline $11-15 \mathrm{yll}$ & 86 & 16.4 \\
\hline $16-40$ yll & 91 & 17.4 \\
\hline \multicolumn{3}{|l|}{ Bası yarası bilgi kaynağı } \\
\hline Hizmetiçi Eğitim & 389 & 74.4 \\
\hline Konferans & 98 & 18.7 \\
\hline Ürün Promosyonları & 36 & 6.9 \\
\hline \multicolumn{3}{|c|}{ En son katıldığı hizmetiçi eğitim } \\
\hline Hiç Katılmadı & 80 & 15.3 \\
\hline 1 Yll İçinde & 145 & 27.7 \\
\hline $1-2$ Yll & 144 & 27.5 \\
\hline 2 Yıldan Fazla & 154 & 29.4 \\
\hline \multicolumn{3}{|l|}{$\begin{array}{l}\text { Bası yarası olan hastaya } \\
\text { bakım verme durumu }\end{array}$} \\
\hline Evet & 409 & 78.2 \\
\hline Hayır & 114 & 21.8 \\
\hline
\end{tabular}

ların, hizmet içi eğitim alanların bası yarasını tedavi etmeye yönelik bilgi puan ortalamalarının istatistiksel açıdan da anlamlı şekilde yüksek olduğu belirlendi $(p<0.05)$. Diğer demografik değişkenler ile hemşirelerin bası yarasını önlemeye ve tedavi etmeye yönelik bilgi puan ortalamaları arasından istatistiksel anlamlı farklılık bulunmadı ( $p>0.05)$.

Hemşirelerin bası yarasını önlemeye yönelik bilgi düzeyi anketine verdikleri yanıtların dağılımı Tablo 3'de görülmektedir. Buna göre hemşirelerin tamamına yakını "Bası yarası gelişme riski olan hastaların beslenme ihtiyaçları değerlendirilir ve yönetimi sağlanır" (\%97.7) "Hastada bası yarası mevcutsa yeni lezyonları önlemek üzere tedbirler alınır" (\%98.5) , "Bası yarasını önlemek ve tedavi etmek için uygulanan bakım kayıt edilir" (\%97.9) madde-
Tablo 2: Hemşirelerin demografik özellikleri ile bası yarasını önleme ve tedavi etmeye yönelik bilgi puan ortalamalarının karşılaştırılması

\begin{tabular}{|c|c|c|}
\hline & $\begin{array}{c}\text { Önleme Bilgi } \\
\text { Puanı } \\
\text { X } \pm \text { SD }\end{array}$ & $\begin{array}{c}\text { Tedavi Etme Bilgi } \\
\text { Puanı } \\
\text { X } \pm \text { SD }\end{array}$ \\
\hline Yaş (31.14 66.29$)$ & $15.63 \pm 1.82$ & $15.69 \pm 2.01$ \\
\hline$r \quad p$ & $0.04 \quad 0.322$ & $0.15 \quad 0.000^{*}$ \\
\hline Çalışma yılı (9.12 \pm 7.08$)$ & $15.63 \pm 1.82$ & $15.69 \pm 2.01$ \\
\hline $\mathrm{r} \quad \mathrm{p}$ & $0.05 \quad 0.204$ & $0.17 \quad 0.000^{*}$ \\
\hline \multicolumn{3}{|l|}{ Cinsiyet } \\
\hline Erkek & $15.25 \pm 1.96$ & $15.18 \pm 2.16$ \\
\hline Kadın & $15.69 \pm 1.79$ & $15.76 \pm 1.98$ \\
\hline $\mathrm{p}$ & 1.810 .070 & $2.21 \quad 0.027^{*}$ \\
\hline \multicolumn{3}{|l|}{ Eğitim durumu } \\
\hline Sağlık meslek lisesi & $15.29 \pm 1.96$ & $15.39 \pm 2.40$ \\
\hline Önlisans & $15.60 \pm 1.74$ & $15.87 \pm 1.72$ \\
\hline Lisans & $15.71 \pm 1.78$ & $15.74 \pm 1.93$ \\
\hline \multirow[t]{2}{*}{ Yükseklisans } & $15.79 \pm 2.02$ & $15.33 \pm 2.42$ \\
\hline & $\mathrm{F}=1.21 \mathrm{p}=0.305$ & $K W=1.43 p=0.697$ \\
\hline \multicolumn{3}{|l|}{ Hastane türü } \\
\hline Devlet hastanesi & $15.83 \pm 1.70$ & $15.78 \pm 1.77$ \\
\hline Üniversite hastanesi & $15.47 \pm 1.89$ & $15.61 \pm 2.18$ \\
\hline $\mathrm{t} \quad \mathrm{p}$ & $2.280 .023^{\star}$ & $0.97 \quad 0.332$ \\
\hline \multicolumn{3}{|l|}{ Çalıştığı birim } \\
\hline Dahili birimler & $15.97 \pm 1.79$ & $15.92 \pm 1.73$ \\
\hline Cerrahi birimler & $15.28 \pm 1.93$ & $15.33 \pm 2.33$ \\
\hline Yoğun bakım üniteleri & $15.14 \pm 1.68$ & $15.32 \pm 2.27$ \\
\hline Acil birim & $15.90 \pm 1.46$ & $16.32 \pm 1.40$ \\
\hline & $\mathrm{F}=7.57 \mathrm{p}=0.000^{*}$ & $K W=12.84 p=0.005^{*}$ \\
\hline \multicolumn{3}{|l|}{ Bilgi kaynakları } \\
\hline Hizmetiçi eğitim & $15.73 \pm 1.83$ & $15.84 \pm 1.97$ \\
\hline Kongre, seminer vb & $15.53 \pm 1.76$ & $15.40 \pm 2.10$ \\
\hline Ürün promosyonları & $14.91 \pm 1.62$ & $14.80 \pm 1.83$ \\
\hline $\mathrm{p}$ & $3.520 .030^{*}$ & $5.70 \quad 0.004^{*}$ \\
\hline
\end{tabular}

lerine doğru yanıt verdi. En az oranda da "Tüm hastalar bası yarası gelişme riski yönünden değerlendirilir” (\%20.3) ve "Kızarmış deriyi korumak için nemlendirici krem kullanılır" (\%36.1) yanlış yanıtını vererek doğru yanıtlamışlardir (Tablo 2).

Hemşirelerin bası yarasını tedavi etmeye yönelik bilgi düzeyi anketine verdikleri yanıtlara göre dağlımı Tablo 4'de verildi. Buna göre ankete katılan hemşirelerin \%97.9 gibi eşit oranlarda "Bası yarasının azalması için havalı yataklar, basınç tedavisi, köpük kaplama, jel pedler kullanılır" ve "Bası yarası pürülan akıntı, koku, patolojik bulgulara ve osteomyelit gibi enfeksiyon belirtileri açısından izlenir" maddelerini doğru şeklinde işaretleyerek doğru yanıtladıkları belirlendi. Hemşirelerin aynı tabloda \%84.7'sinin "Bası yarasında enfeksiyon belirtileri görüldügünde topikal antibiyotik kullanılır" maddesini doğru şeklinde işaretleyerek yanlış yanıt verdikleri saptandı (Tablo 3). 
Table 3: Hemşirelerin bası yarasını önlemeye yönelik bilgi düzeyi anketine verdikleri yanıtlara göre dağllımı ( $\mathrm{n}=523)$

\begin{tabular}{|c|c|c|c|c|}
\hline & $\begin{array}{c}\text { DOĞRU } \\
n^{*}\end{array}$ & $\%$ ** & $\begin{array}{c}\text { YANLIS } \\
n^{*}\end{array}$ & $\%$ ** \\
\hline 1. Bası yarası oluşma riski Braden ölçeğiyle incelenir.(D) & 438 & 83.7 & 85 & 16.3 \\
\hline $\begin{array}{l}\text { 2. Bası yarası gelişme riski olan hastaların beslenme ihtiyaçları } \\
\text { değerlendirilir ve yönetimi sağlanır.(D) }\end{array}$ & 506 & 96.7 & 17 & 3.3 \\
\hline 3. Bası yarası gelişimi ile ilgili ağrı durumu değerlendirilir ve ağıı yönetimi uygulanır.(D) & 499 & 95.4 & 24 & 4.6 \\
\hline 4. Sıcak kompres uygulanır.(Y) & 422 & 80.7 & 101 & 19.3 \\
\hline $\begin{array}{l}\text { 5. Hastanın pozisyonunu değiştirirken kayan çarşaf,kayan tahta ya da } \\
\text { kaldırma yönteminden yararlanılır.(Y) }\end{array}$ & 116 & 22.2 & 407 & 77.8 \\
\hline 7. Her 4 saatte bir hasta 90 derece yan yatırılır.(Y) & 356 & 68.1 & 167 & 31.9 \\
\hline 8. Önlemek üzere koyun derisi kullanılır.(Y) & 418 & 79.9 & 105 & 20.1 \\
\hline $\begin{array}{l}\text { 9. Bası yarası riski altındaki tüm bireylere en az haftada bir kez sistematik } \\
\text { bir cilt muayenesi yapılır.(D) }\end{array}$ & 407 & 77.8 & 116 & 22.2 \\
\hline 10. Tüm hastalar bası yarası gelişme riski yönünden değerlendirilir.(Y) & 106 & 20.3 & 417 & 79.7 \\
\hline 11. Hasta yatakta yan olarak 30 derecelik bir açıyla yatırılır.(D) & 307 & 58.7 & 216 & 41.3 \\
\hline 16. Besin bozukluğu olan hastalar değerlendirilir, desteklenir ve korunur.(D) & 508 & 97.1 & 15 & 2.9 \\
\hline 17. Hastanın sağlık durumu kötüyse (yatak içinde) hareket ettirilmez.(Y) & 458 & 87.6 & 65 & 12.4 \\
\hline 18. İnkontinans, terleme, yara drenajı nedeniyle aşırı nem oluşumu önlenir.(D) & 505 & 96.6 & 18 & 3.4 \\
\hline 19. Hemşire ve bakım verenler bası yarası önleme ilkeleri hakkında eğitilir.(D) & 510 & 97.5 & 13 & 2.5 \\
\hline 20. Ciltteki kuruluğu önlemek için cilt ıslak pamukla nemlendirilir.(Y) & 404 & 77.2 & 119 & 22.8 \\
\hline
\end{tabular}

*Birden fazla yanıt verilmiştir. * * Yüzdeler n (523) sayısına göre alınmıştır.

\section{TARTIŞMA}

Çalışmada, hemşirelerin bası yarasını önleme bilgilerinin orta düzeyde olduğu belirlendi. Konu hakkında önceki çalışmalarda farklı sonuçlar elde edilmiştir. Hulsenboom ve arkadaşları tarafından yapılan benzer bir çalışmada, hemşirelerin önleyici bilgilerinin orta düzeyde olduğu bildirilmiştir (11). Doğu'nun yoğun bakım hemşireleri ile gerçekleştirdiği ön test-son test çalışmada da hemşirelerin eğitim öncesi bası yarasına ilişkin bilgilerinin orta düzeyde olduğu belirtilmiştir (1). Akese ve arkadaşları, Pancorbo-Hidalgo ve arkadaşları ile Källman ve Suserud hemşirelerin bası yarasının önlemeye yönelik bilgi düzeylerini inceledikleri çalışmalarında da, hemşirelerin yüksek düzeyde bilgiye sahip oldukları bildirilmiştir (13-15). Ancak Nuru ve arkadaşlarının, Aydın ve Karadağ'ın, Qaddumi ve Khawaldeh'in ve Demarré ve arkadaşlarının hemşirelerin bası yarasını önleme hakkındaki bilgi durumlarını değerlendirdikleri çalışmalarda ise, hemşirelerin yetersiz bilgiye sahip oldukları ifade edilmiştir (16-19).

Bu güncel çalışmada, devlet hastanesinde ve dahili birimlerde çalışan ve hizmet içi eğitim alan hemşirelerin bası yarasını önleme bilgi puanlarının anlamlı şekilde yüksek saptandı. Hemşirelerin yaşı, çalışma yılı ve eğitim durumlarının basınç yarasını önleme bilgi puanlarında etkili olmadığı belirlendi. Bu bulgular, Hulsenboom ve arkadaşlarının yaş ve çalışma yılının hemşirelerin bası yarasını önleme bilgisini etkilemediği çalışma bulgusu ile paralellik göstermektedir (11). Ayrıca bu bulgular, Aydın ve Karadağ'ın hizmet içi eğitim alan hemşirelerin ve Nuru ve arkadaşlarının, Pancorbo-Hidalgo ve arkadaşlarının, hemşirelerin bası yarasına yönelik aldıkları formal eğitimin bilgi puanlarının artışında etkili olduğu çalışma bulguları ile benzerlik göstermektedir $(14,16,17)$. Ancak aynı üç çalışma ile Hulsenboom ve arkadaşlarının çalışma sonuçlarında, bu çalışmadan farklı olarak hemşirelerin eğitim durumlarının bilgi puanlarında anlamlı etki gösterdiği bildirilmiştir $(11,14,16,17)$. Tubaishat ve arkadaşlarının ve ülkemizde Sarı'nın yapmış olduğu çalışmalarda ise, hemşirelerin eğitim düzeyi ile bası yarasını önlemeye yönelik bilgi düzeyleri arasında anlamlıık bulunmamıştır $(12,20)$. Aydın ve Karadağ'ın Türkiye'deki hemşireler ile yaptığı çalışmasında, hemşirelerin çalışma ile bası yarasını önleme ve yönetimi bilgi puanları arasında anlamlı farklılık bulunmamıştır (17).

Çalışmada hemşirelerin bası yarasını önlemek için bilgi anketinde en sık hastaların beslenme ihtiyaçlarının değerlendirilmesi, önleyici tedbirlerin alınması ve kayıt altına alma maddelerine doğru yanıt verdikleri belirlendi. 
Table 4: Hemşirelerin bası yarasını tedavi etmeye yönelik bilgi düzeyi anketine verdikleri yanıtlara göre dağlımı $(n=523)$

\begin{tabular}{|c|c|c|c|c|}
\hline & \multicolumn{2}{|c|}{ DOĞRU } & \multicolumn{2}{|c|}{ YANLIŞ } \\
\hline & $\mathrm{n}$ & $\%$ & $\mathrm{n}$ & $\%$ \\
\hline $\begin{array}{l}\text { 1. Bası yarası yer, büyüklük, grade, yatak yarası, eksüda,ağrı,çevrelediği } \\
\text { doku ve zarar günlük ya da haftalık olarak değerlendirilir.(D) }\end{array}$ & 485 & 92.7 & 38 & 7.3 \\
\hline 3. Bası yarası oluşmuş hastalar için tam bir fizik muayene yapılır.(D) & 490 & 93.7 & 33 & 6.3 \\
\hline 4. Yara olan ekstremite tahta parçalarıyla desteklenir.(Y) & 450 & 86.0 & 73 & 14.0 \\
\hline $\begin{array}{l}\text { 5. Bası yarasının azalması için havalı yataklar, basınç tedavisi, } \\
\text { köpük kaplama,jel pedler kullanılır.(D) }\end{array}$ & 97.9 & 11 & 2.1 & 512 \\
\hline 7. Bası yarası $\% 0.9 \mathrm{NaCl}$ kullanılarak temizlenir.(D) & 465 & 88.9 & 58 & 11.1 \\
\hline 8. Bası yarası hidrokolloid gibi nemli örtüyle kapatılır.(D) & 439 & 83.9 & 84 & 16.1 \\
\hline $\begin{array}{l}\text { 9. Bası yarası pürülan akıntı,koku,patolojik bulgulara ve osteomyelit } \\
\text { gibi enfeksiyon belirtileri açısından izlenir.(D) }\end{array}$ & 512 & 97.9 & 11 & 2.1 \\
\hline $\begin{array}{l}\text { 10. Bası yarası enfeksiyona sahip ya da osteomyelit belirtisi gösteren hastalara } \\
\text { bakım verirken aseptik tekniğe dikkat edilir.(D) }\end{array}$ & 506 & 96.7 & 17 & 3.3 \\
\hline 13. Bası yarası tedavisi için bal,ısı ya da diğer preparatlar gibi alternatif metodlar kullanılır.(Y) & 419 & 80.1 & 104 & 19.9 \\
\hline 14. Bası yarası temizliğinde povidin iyodin $\mathrm{H} 2 \mathrm{O} 2$,kloreksidin gibi antiseptikler kullanılır.(Y) & 194 & 37.1 & 329 & 62.9 \\
\hline 15. Bası yarası için kuru gazlı bez ya da iyodine bastırılmış gazlı bez gibi kuru örtüler kullanılır.(Y) & 197 & 37.7 & 326 & 62.3 \\
\hline 16. Bası yarasının durumu ne olursa olsun üzerindeki örtü günlük olarak değiştirilir.(Y) & 204 & 39.0 & 319 & 61.0 \\
\hline 17. Bası yarasında enfeksiyon belirtileri görüldüğünde topikal antibiyotik kullanılır.(Y) & 80 & 15,3 & 443 & 84.7 \\
\hline 18. Enfekte olan bası yarasından alınan kültüre göre antibiyotik seçimi yapılır.(D) & 507 & 96.9 & 16 & 3.1 \\
\hline 19. Yara için sıcak su ve sabun kullanılır.(Y) & 451 & 86.2 & 72 & 13.8 \\
\hline 20. Hastaların hastalık boyunca protein-kalori ihtiyaçlarına uygun diyet alımı sağlanır.(D) & 503 & 96.2 & 20 & 3.8 \\
\hline
\end{tabular}

Bu sonuçların önceki çalışmalar ile uyumlu olduğu belirlenmiştir. Literatürde iyileştirmek için beslenmenin son derece önemli olduğu belirtilmektedir. Ayrıca Saleh ve arkadaşları, Sarı ve Hulsenboom ve arkadaşlarının yaptıkları çalışmalarda da hemşirelerin hastaların beslenme durumlarının değerlendirmesi ve sürdürülmesine yüksek oranda doğru cevap verdikleri belirlenmiştir $(6,11,12)$. Källman ve Suserud tarafından yapılan bir çalışmada ise, bası yarasını önleyici tedbirlerin alınması gerekliliğini hemşirelerin bildirdikleri, kayıt altına almada hemşirelerin yetersiz oldukları görülmüştür (15).

Çalışmada, hemşirelerin bası yarasını tedavi etme bilgilerinin orta düzeyde olduğu belirlendi. Hemşirelerin yaşının, cinsiyetinin, çalışma yılının, çalıştıkları birimin, hizmet içi eğitim almanın bası yarasını tedavi etmeye yönelik bilgi puan ortalamalarını anlamlı şekilde etkilediği saptandı. Källman ve Suserud tarafından yapılan bir çalışmada, hemşirelerin bası yarasını tedavi etme bilgilerinin iyi olduğu belirtilmiştir (15). Lawrence ve arkadaşları tarafından yapılan çalışmada, hemşirelerin bası yarası yönetimi hakkındaki bilgilerini memnuniyet verici olarak değerlendirilmiş olup hemşirelerin deneyim yılının bilgi puanlarını olumlu yönde etkilediği bildirilmiştir (21). Pancorbo-Hidalgo ve arkadaşları yaptıkları çalışma sonuçla- rında da hemşirelerin bası yarasını yönetme hakkındaki bilgi durumlarını iyi düzeyde olarak ifade etmişler, üniversite mezunu olan hemşirelerin bilgi puanının anlamlı şekilde arttığını belirtmişlerdir (14). Saleh ve arkadaşlarının çalışmasında, bu çalışma sonuçlarına benzer şekilde, hemşirelerin çalışma deneyimi ile bası yarasını yönetmeye yönelik bilgi düzeyleri arasında anlamlı farklılık saptanmıştır (6). Doğu'nun yoğun bakım hemşireleri ile yaptığı çalışmada bası yarası, bakımı ve bakım ürünleri kullanımına ilişkin verilen eğitimin bilgi puanlarını arttığı belirtilmiştir (1). Feng ve arkadaşları çalışma sonuçlarında, iki yıl süreyle eğitim verilen hemşirelerin bası yarası yönetimine ilişkin bilgilerinin arttığını ve basınç yarasının görülme sıklığının azaldığını bildirmişlerdir (22). Hemşirelerin bilgi düzeyleri dışında bası yarasını yönetme bilgisi ile çalışma yılı, eğitim durumu, hizmet içi eğitim arasındaki ilişki sonuçları önceki çalışmalar ile paralellik göstermiştir.

Güncel çalışmada hemşirelerin bası yarasını yönetmeye yönelik bilgi anketinde en sık "Bası yarasının azalması için havalı yataklar, basınç tedavisi, köpük kaplama, el pedler kullanılır" ve "Bası yarası pürülan akıntı, koku, patolojik bulgular ve osteomyelit gibi enfeksiyon belirtileri açısından izlenir" maddelerini doğru yanıtladıkları 
belirlendi. Källman ve Suserud tarafından yapılan bir çalışmada da hemşirelerin bası yarasında basıncı azaltıcı önlemlerin alınması gerektiğini bildirdikleri belirlenmiştir (14). Ayrıca, bu sonucun literatür bilgisi uyumlu olduğu görülmüştür $(23,24)$.

Sonuç olarak alandaki çalışmalara ve eğitim stratejilerine katkı sağlayacak bu çalışma; hemşirelerin bası yara- sını önleme ve yönetmeye yönelik bilgilerinin orta düzeyde olduğunu, bu puanlar ile hemşirelerin çalıştığı birim, çalışma yıll, eğitim durumu ve hizmet içi eğitim alma durumları arasında anlamlı farklılık olduğunu gösterdi. Bu bağlamda; hemşirelerin akademik ve hizmet içi eğitim programlarında bası yarasının önlenmesi ve tedavisi konusuna daha fazla yer verilmesi önerilmektedir.

\section{KAYNAKLAR}

1. Doğu Ö. Yoğun bakım hemşirelerinin bası yarası, bakımı ve bakım ürünleri kullanımına ilişkin bilgi ve uygulamalarının değerlendirilmesi. J Hum Rhythm 2015; 1: 95-100.

2. Karadağ A. Basınç ülserleri: değerlendirme, önleme ve tedavi. Cumhuriyet Üniversitesi Hemşirelik Yüksekokulu Dergisi 2003; 7 : 41-48.

3. Kelebek Girgin N, Kurhan Erarı G. Basınç yarası bakımı. Türk Yoğun Bakım Derneği Dergisi 2007; 11-13.

4. Islam S, Sorsia W, Khupantauee N. Knowledge attitude and practice on pressure ulcer prevention among nurses in Bangladesh. The 2nd international conference on humanities and social sciences April 10th,2010 Faculty of liberal arts, Prince of Songkla University diseases palliative care 2010; 011 .

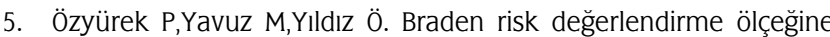
göre yoğun bakım ünitelerinde yatan hastalarda risk ve insidans incelemesi. 8.Ulusal Dahili ve Cerrahi Bilimler Yoğun Bakım Kongresi, Ankara, 2011.

6. Saleh YN, Al-Hussami M, Anthay DM. Pressure ulcer prevention and treatment knowledge of Jordanian nurses. J Tissue Viability 2013; 22: $1-11$.

7. Prevention and treatment of pressure ulcers: clinical practice guideline. National Pressure Ulcer Advisory Panel and European Pressure Ulcer Advisory Panel, Washington DC, 2009.

8. Clarke H, Bradley C, Whytock S, Handfield S, van der Wal R, Gundry S. Pressure ulcers: implementation of evidence-based nursing practice. J Advanced Nursing 2005; 49: 578-90.

9. Tel H, Özden D, Güneş Çetin P.Yatağa bağımlı hastalarda basınç yarası gelişme riski ve hemşirelerin bu hastalara uyguladıkları önleyici bakım. Hemşirelikte Araştırma ve Geliştirme Dergisi 2006; 1: 35-45.

10. Uzun Ö. Cerrahi hastalarda basınç ülserlerinin önlenmesi. Fırat Sağlık Hizmetleri Dergisi 2010; 5: 113-127.

11. Hulsenboom MA, Bours GJJW, Halfens RJG. Knowledge of pressure ulcer prevention:a cross-sectional and comparative study among nurses. BMC Nursing 2007; 6:2.

12. Sarı E. Yoğun bakım hemşirelerinin basınç ülseri hakkındaki bilgi düzeyleri. Akad Geriatri 2013; 5: 73-79.

13. Akese MI, Adejumo PO, Ilesanmi RE, Obilor HN. Assessment of nurses' knowledge on evidence-based preventive practices for pressure ulcer risk reduction in patients with impaired mobility. Afr J Med Med Sci. 2014; 43: 251-258.

14. Pancorbo-Hidalgo PL, García-Fernández FP, López-Medina IM, López-Ortega J. Pressure ulcer care in Spain: nurses' knowledge and clinical practice. J Adv Nurs 2007; 58: 327-338

15. Källman U, Suserud BO. Knowledge, attitudes and practice among nursing staff concerning pressure ulcer prevention and treatment-a survey in a Swedish healthcare setting. Scand J Caring Sci 2009; 23: $334-341$

16. Nuru N, Zewdu F, Amsalu S, Mehretie Y. Knowledge and practice of nurses towards prevention of pressure ulcer and associated factors in Gondar University Hospital, Northwest Ethiopia. BMC Nurs 2015; 14: 34.

17. Aydin AK, Karadağ A. Assessment of nurses' knowledge and practice in prevention and management of deep tissue injury and stage I pressure ulcer. J Wound Ostomy Continence Nurs. 2010; 37: 487-494.

18. Qaddumi J, Khawaldeh A. Pressure ulcer prevention knowledge among Jordanian nurses: a cross- sectional study. BMC Nurs. 2014; 13(1):6.

19. Demarré L, Vanderwee K, Defloor T. Pressure ulcers: knowledge and attitude of nurses and nursing assistants in Belgian nursing homes. J Clin Nurs 2012;21: 1425-1434.

20. Tubaishat A, Aljezawi M, Al Quadire M. Nurses' attitudes and perceived barriers to pressure ulcer prevention in Jordan. Journal of Wound Care 2013; 22(9): 490-497.

21. Lawrence P, Fulbrook P, Miles S. A Survey of Australian Nurses' Knowledge of Pressure Injury/Pressure Ulcer Management. J Wound Ostomy Continence Nurs. 2015; 42(5):450-60.

22. Feng $\mathrm{H}, \mathrm{Li} \mathrm{G}, \mathrm{Xu} \mathrm{C}$, Ju C. Educational campaign to increase knowledge of pressure ulcers. Br J Nurs 2016; 25(12):S30-5.

23. Taşcı Bozbaş G, Gürer G. Bası yaralarında güncel tedavi yaklaşımları. Sakarya Tıp Dergisi 2011; (4):118-125.

24. Dündar D, Keçeli Özcan S, Atmaca E. Evde bakım hizmeti verilen hastaların bası yaralarındaki yüzeyel kolonizasyonun mikrobiyolojik incelenmesi. Kocatepe Tıp Dergisi 2012; 13: 27-32. 